\title{
Sniking i sykehuskøen
}

Tidsskriftet har endret utseende og innhold over tid. I nr. 2/1920 var det mange små kunngjøringer, stoff som ikke får særlig plass i dagens spalter. Tematikken fra eksemplet her er derimot kjent - køsniking i helsevesenet. Dette var en inderlig oppfordring om at leger ikke skulle presse inn sine pasienter ved sykehus, men la dem følge «ventelistene» (Tidsskr Nor Lægeforen 1920; 40: 86).

\section{Indlæggelse for «øieblikkelig hjælp» i Rikshospitalet. Fra Rikshospitalets direktør.}

Rikshospitalets direktør advarer paany indtrængende mot uberettiget indsendelse av patienter «for øieblikkelig hjælp». Patienter, som paa denne maate, til fortrængsel for andre, søkes indsmuglet før sin tur, vil bli avvist eller straks hjem sendt uten at tages under behandling.

Forøvrig henvises til tidligere henstillinger i «Tidsskriftet» bl.a. i nr. 2, for 1915 (s. 96).

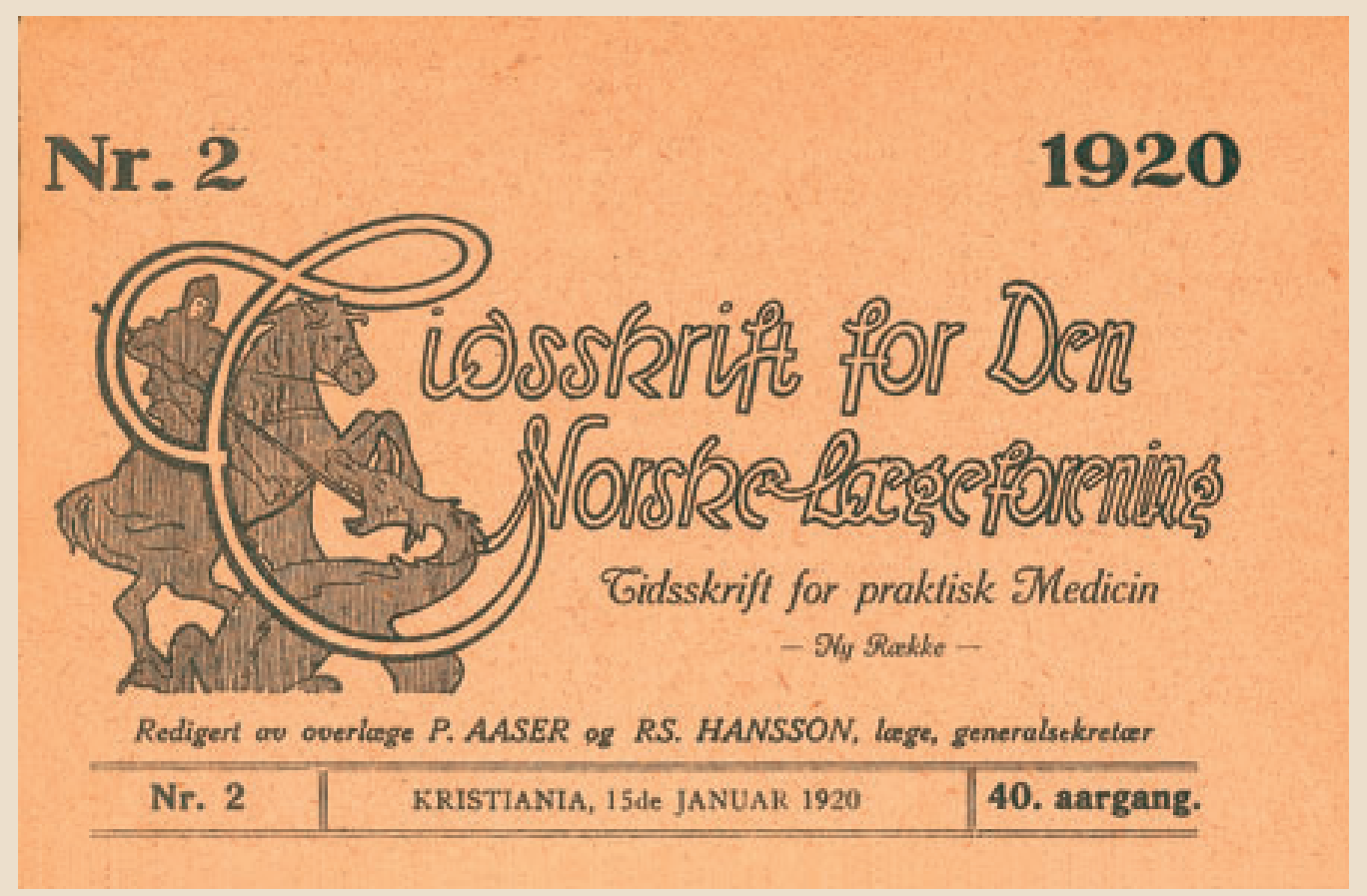

